УДК $347.1+347.2 / .3+349.41$

DOI https://doi.org/10.32782/2409-4544/2020-1/10

Ю. Носік

\title{
Реалізація принципів цивільного права у відносинах купівлі-продажу земельної ділянки сільськогосподарського призначення
}

Стаття присвячена дослідженню теоретичних $\mathrm{i}$ практичних проблем, пов'язаних 3 закріпленням в законодавстві України переважного права на купівлю земельної ділянки сільськогосподарського призначення, пошуку i обгрунтування можливих шляхів їх вирішення, виходячи 3 основоположних принципів цивільного права. Автор зробив висновок про те, що переважне право купівлі земельної ділянки сільськогосподарського призначення, передбачене у ч. 2 ст. 130 Земельного кодексу України, за своєю правовою природою істотно відрізняється від інших переважних прав купівлі майна, закріплених в законодавстві України, і не узгоджується з концепцією, призначенням і механізмом реалізації таких прав. Це право не обумовлено іншими цивільними правами відповідних суб'єктів; надається законом суб'єктам за територіальним критерієм; не має функціонального призначення та цілі, як інші переважні права. Крім того, право переважної купівлі земельної ділянки сільськогосподарського призначення несе корупційні ризики і створює передумови для зловживання правом. На підставі зроблених висновків автор пропонує вдосконалити законодавство про купівлю-продаж земельних ділянок сільськогосподарського призначення шляхом скасування частини 2 ст. 130 Земельного кодексу України. Прогалини регулювання та недосконалість формулювання норми ч. 2 ст. 130 ЗК України не забезпечують належних умов для ефективної реалізації та дієвого захисту цього права. Як наслідок, вирішення існуючих проблем у сфері правозастосування цієї норми може бути здійснене лише виходячи 3 таких приниципів цивільного права як розумність, добросовісність, свобода договору і судовий захист цивільного права та інтересу.

Ключові слова: переважне право, купівля-продаж, земельна ділянка сільськогосподарського призначення, принципи цивільного права.

Постановка наукової проблеми та її значення. Однією з особливостей регулювання правовідносин, пов'язаних із укладенням договору купівлі-продажу земельної ділянки сільськогосподарського призначення, є закріплення переважного права купівлі земельних ділянок сільськогосподарського призначення за певним колом суб'єктів. У ч. 2 ст. 130 ЗК України встановлено, що переважне право купівлі земельних ділянок сільськогосподарського призначення мають громадяни України, які постійно проживають на території відповідної місцевої ради, де здійснюється продаж земельної ділянки, а також відповідні органи місцевого самоврядування.

Науковий аналіз наведеної правової норми а також практика іiі реального застосування свідчить про існування проблем як прикладного, так і теоретичного характеру, які породжують перешкоди в реалізації суб'єктивних прав власника на розпорядження належною йому земельною ділянкою i, відповідно, вимагають пошуку шляхів їх усунення.

Аналіз досліджень цієї проблеми. В доктрині цивільного права України досить ретельно опрацьовані переважні права як вид суб'єктивних цивільних прав. Свої наукові праці присвятили їм такі вчені, як І. Я. Бабецька, В. В. Боднар, В. І. Крат, В. В. Луць., Н. І. Майданик, Р. А. Майданик, I. В. Спасибо-Фатєєва, С. І. Шимон та інші дослідники. Разом 3 тим, переважне право купівлі земельної ділянки сільськогосподарського призначення, хоч і згадується у деяких працях вчених, не ставало предметом самостійного вивчення. Також у спеціальній фаховій літературі недостатньо висвітлені проблеми правового регулювання зазначеної сфери суспільних відносин та не здійснено грунтовного пошуку можливих шляхів їх вирішення.

Формулювання мети та завдань статті. Ця стаття присвячена висвітленню теоретичних і практичних проблем, які пов'язані із закріпленням в законодавстві України переважного права на купівлю земельної ділянки сільськогосподарського призначення, та пошуку й обгрунтуванню можливих шляхів їх вирішення, виходячи з основоположних принципів цивільного права та основних засад цивільного законодавства. Досягнення зазначеної мети пов'язане, зокрема, з виконанням таких

() Носік Ю., 2020 
завдань: визначення змісту і правової природи переважного права, закріпленого у ч. 2 ст. 130 ЗК України; встановлення кола учасників та ідентифікація об'єктів правовідносин, що регулюються даною нормою права; з'ясування порядку реалізації та способів захисту досліджуваного суб' єктивного права; обгрунтування шляхів вирішення теоретичних і практичних проблем в окреслені сфері на засадах принципів цивільного права.

Виклад основного матеріалу й обгрунтування отриманих результатів дослідження. Закріплення права переважної купівлі певних об'єктів застосовується в цивільному законодавстві України як юридичний механізм охорони суб'єктивних інтересів осіб у певних ситуаціях, як забезпечення суспільного інтересу або як спосіб подолання подрібленості суб'єктивних прав на один об'єкт. Наприклад, ст. 362 ЦК України встановлює право переважної купівлі частки у праві спільної часткової власності; ст. 777 і 822 ЦК України - переважне право наймача на укладення договору найму на новий строк, а також на придбання предмету найму в разі його продажу; ст. 1156 ЦК України - переважне право засновника конкурсу на укладення з переможцем конкурсу договору про використання предмета конкурсу; Закон України «Про товариства з обмеженою та додатковою відповідальністю» - переважне право учасників товариства на додатковий вклад до статутного капіталу та на придбання частки іншого учасника, що продається третій особі; Закон України «Про акціонерні товариства» - переважне право акціонерів приватного акціонерного товариства на придбання акцій цього товариства, що пропонуються їх власником до відчуження третій особі, а також переважне право акціонерів при додатковій емісії акцій. Наведений перелік прикладів не $\epsilon$ вичерпним.

Передбачене ч. 2 ст. 130 ЗК України переважне право купівлі земельної ділянки сільськогосподарського призначення $\epsilon$ правом, зміст якого становить передбачена законом можливість громадянина України, який проживає постійно на території місцевої ради, де здійснюється продаж земельної ділянки сільськогосподарського призначення, а також відповідних органів місцевого самоврядування придбати у власність відчужувану шляхом купівлі-продажу земельну ділянку переважно перед фізичними особами, які не проживають постійно на території відповідної місцевої ради, та перед усіма юридичними особами.

Це переважне право виникає лише у випадку відчуження земельної ділянки сільськогосподарського призначення шляхом iï купівлі-продажу. Воно не виникає, коли земельна ділянка відчужується будь-яким іншим способом (дарування, міна, внесення до статутного капіталу тощо). Ч. 2 ст. 130 ЗК України підлягає застосуванню у всіх випадках купівлі-продажу земельних ділянок сільськогосподарського призначення, крім земельних торгів (абз. 2 ч. 2 ст. 135 ЗК України). У період дії мораторію на відчуження земельних ділянок сільськогосподарського призначення, що встановлений п. 15 Розділу $\mathrm{X}$ «Перехідні положення» Земельного кодексу України, вона застосовується до купівлі-продажу тих ділянок, які лишились неохопленими мораторієм, зберігають свою оборотоздатність і можуть виступати предметом договору купівлі-продажу.

Право переважної купівлі земельної ділянки сільськогосподарського призначення не $\epsilon$ обмеженням або обтяженням права власності на таку ділянку, а лише особливим порядком іiі відчуження у формі купівлі-продажу. Це право не обмежує коло покупців земельної ділянки сільськогосподарського призначення, адже за відмови суб' єктів переважного права скористатись ним таку ділянку може придбати будь-яка інша особа, якій законом не заборонено набувати у власність земельні ділянки сільськогосподарського призначення. В договірних відносинах купівлі-продажу особа покупця не має істотного значення для продавця, відтак йому байдуже, чи покупцем буде суб'єкт переважного права на ії купівлю, чи третя особа.

У цивілістичній доктрині право переважної купівлі майна характеризується ознакою детермінованості кола осіб, яким воно належить. Зокрема, Н. І. Майданик зазначає, що таке право «забезпечує визначеному колу осіб привілей на придбання певного майна» [1, с. 849]. Відтак слід 3'ясувати, чи $є$ коло осіб, якому належить переважне право купівлі земельної ділянки сільськогосподарського призначення, визначеним.

Як передбачено ч. 2 ст. 130 ЗК України, суб'єктами досліджуваного права є громадяни України, які постійно проживають на території відповідної місцевої ради, де здійснюється продаж земельної ділянки, та відповідні органи місцевого самоврядування. Визначати органи місцевого самоврядування, які можуть вступати у відносини купівлі земельної ділянки, необхідно 3 урахуванням положень Конституції України, ЗК України та Закону України «Про місцеве самоврядування в Україні». А до кола громадян України, які постійно проживають на території відповідної місцевої ради, належать, виходячи з положень Закону України «Про свободу пересування та вільний вибір місця проживання в Україні», фізичні особи з числа громадян України, адреси 
реєстрації місця проживання яких зареєстровані на території відповідної місцевої ради. В часовому вимірі таке коло громадян України, які постійно проживають на території відповідної місцевої ради, має фіксуватись на момент, коли стає відомим волевиявлення власника продати належну йому земельну ділянку сільськогосподарського призначення.

Отже, коло осіб, яким належить переважне право купівлі земельної ділянки сільськогосподарського призначення, можна вважати визначеним, хоч і не персоніфікованим. Дві категорії осіб, які є суб' єктами цього права (громадяни україни та органи місцевого самоврядування), ідентифікуються за територіальним критерієм, і кількісно можуть становити досить об'ємне коло суб'єктів.

Разом 3 тим, формулювання норми ч. 2 ст. 130 ЗК України вносить серйозні проблеми у практичне визначення кола громадян України та органів місцевого самоврядування, яким належить переважне право купівлі земельної ділянки сільськогосподарського призначення. В зазначеній нормі використовується зворот «територія відповідної місцевої ради, де здійснюється продаж земельної ділянки» замість, наприклад, «територія відповідної місцевої ради, де розташована земельна ділянка». Як наслідок, територією, де здійснюється продаж земельної ділянки, може бути зовсім інша адміністративно-територіальна одиниця, аніж та, де земельна ділянка фактично розташована. Це пов' язано з тим, що відповідно до ч. 4 ст. 55 Закону України «Про нотаріат» посвідчення правочинів щодо відчуження земельної ділянки провадиться за місцезнаходженням ділянки або за місцезнаходженням (місцем реєстрації) однієї із сторін відповідного правочину.

Якщо місце реєстрації продавця земельної ділянки знаходиться на території іншої місцевої ради, ніж та, де знаходиться земельна ділянка, і він має намір посвідчувати договір купівлі-продажу ділянки за місцем своєї реєстрації, то в розумінні ч. 4 ст. 55 Закону України «Про нотаріат» територією, де здійснюється продаж земельної ділянки законно можна вважати не територію знаходження ділянки, а територію адміністративно-територіальної одиниці реєстрації продавця. Тоді за цим же територіальним критерієм необхідно визначати і коло громадян України та органів місцевого самоврядування, яким належить переважне право купівлі земельної ділянки сільськогосподарського призначення.

В науці цивільного права переважні права характеризуються як вторинні права. Так, описуючи сутнісні властивості переважних прав В. І. Крат зазначає, що переважне право $\epsilon$ «вторинним стосовно тих суб' єктивних прав, які обумовлюють їх виникнення» [2, с. 5]. Іншими словами такі переважні права виникають лише тому, що в їх суб’єкта вже є певні права, які обумовлюють виникнення переважного права. Наприклад, право переважної купівлі частки у спільній власності виникає у співвласника тому, що йому вже належить право власності на одну з часток; право переважної купівлі акцій приватного акціонерного товариства виникає в акціонера тому, що йому вже належить право власності на якусь частину акцій цього товариства; право переважної купівлі об'єкта найму виникає в наймача тому, що йому вже належить право користування цим майном і т.д.

В. В. Боднар визначає переважне право як «право учасника цивільних відносин на переважне перед іншими особами вчинення дій (правочинів), спрямованих на набуття, зміну або припинення цивільних прав та обов'язків» [3, с. 122]. Тобто, переважне право може виникати в особи, яка вже перебуває у певних цивільних відносинах та володіє деякими суб' єктивними цивільними правами.

Проаналізувавши переважне право купівлі земельної ділянки сільськогосподарського призначення, можна зробити висновок, що воно не $\epsilon$ вторинним. Це право виникає у громадян України, які постійно проживають на території відповідної місцевої ради, не тому, що їм належить якесь суб' єктивне цивільне право, яке обумовлює виникнення переважного права на купівлю ділянки, а лише тому, що такі громадяни проживають в даній місцевості постійно. У відповідних органів місцевого самоврядування це право виникає теж не у зв'язку з якимось іншим цивільним правом, а лише в силу того, що вони є органами місцевого самоврядування на відповідній території.

Викладене свідчить про те, що сутнісні риси переважного права на купівлю земельної ділянки сільськогосподарського призначення тяжіють від ознак суб'єктивного права до ознак елементу правоздатності особи, адже це право належить ій як резиденту певної місцевості, тобто є складовою правового статусу цієї особи на основі фактору місця ії проживання і не має жодного відношення до правового статусу даної особи як учасника цивільних відносин.

Дослідження правової природи переважного права купівлі земельної ділянки сільськогосподарського призначення потребує також з'ясування функціонального призначення цього права. Однак надати раціональну відповідь на питання про те, досягненню якої цілі слугує це право, який приватний або суспільний інтерес ним забезпечується, навряд можливо. Для місцевого 
населення та відповідних органів самоврядування відсутні будь-які ризики від придбання земельних ділянок сільськогосподарського призначення громадянами України, які проживають в іншій місцевості або за кордоном, адже земельні ділянки у просторі не переміщуються, а обов'язки для всіх власників земельних ділянок сільськогосподарського призначення в Україні є однаковими, незалежно від місця проживання власника. Сумнівним є те, що належність земельної ділянки фізичній особі місцевому мешканцю буде запорукою іiі більш ефективного використання чи продуктивнішого господарювання на ній (хоча вирощений урожай транспортувати додому буде таки ближче).

Не знаходиться логічного пояснення також тій обставині, чому в силу ч. 2 ст. 130 ЗК України місцеві мешканці та відповідні органи місцевого самоврядування отримали пріоритетне право придбання земельної ділянки сільськогосподарського призначення не тільки перед громадянами України з інших місцевостей, але й навіть перед юридичними особами, в т.ч. сільськогосподарськими підприємствами, місцезнаходження яких перебуває в межах цієї ж території місцевої ради, де здійснюється продаж земельної ділянки. Відсутність достатнього обгрунтування функціонального призначення переважного права придбання земельної ділянки сільськогосподарського призначення, передбаченого ч. 2 ст. 130 ЗК України, невигідно вирізняє його 3-поміж решти переважних прав, передбачених у законодавстві України.

Охорона приватних інтересів співвласників майна, користувачів найманого майна, учасників господарських товариств достатнім чином обгрунтовує доцільність та необхідність наданого їм законом переважного права купівлі відповідної частки або майна. Очевидними також є ті суспільні інтереси, для забезпечення яких, для прикладу, органи охорони культурної спадщини мають право привілеєвої купівлі пам'ятки відповідно до ст. 20 Закону України «Про охорону культурної спадщини»; релігійні організації мають переважне право на передачу їм культових будівель із земельною ділянкою, необхідною для обслуговування цих будівель, відповідно до ст. 17 Закону України «Про свободу совісті та релігійні організації»; держава має переважне право на купівлю документа Національного архівного фонду відповідно до ст. 10 Закону України «Про Національний архівний фонд та архівні установи»; територіальні громади мають переважне право викупу земель, будинків і споруд для містобудівних потреб відповідно до ст. 21 Закону України «Про основи містобудування» та ін. Навіть передбачене абз. 2 ч. 9 ст. 60 Закону України «Про місцеве самоврядування» право сільських, селищних, міських, районних в місті рад на переважне придбання в комунальну власність приміщень, споруд, інших об'єктів, розташованих на відповідній території, має визначену законом мету - для забезпечення комунально-побутових та соціально-культурних потреб територіальних громад. Однак запровадженню права переважної купівлі органами місцевого самоврядування та місцевими мешканцями земельної ділянки сільськогосподарського призначення у тому вигляді, як це зроблено в ч. 2 ст. 30 ЗК України, належного обгрунтування та пояснення не знаходиться.

За відсутності раціональної мети, для досягнення якої в законодавство України запроваджене переважне право на купівлю земельної ділянки сільськогосподарського призначення, цей механізм створює сприятливі умови для зловживання переважним правом на шкоду вільному цивільному обороту земельних ділянок, а також несе у собі корупційні ризики для місцевого самоврядування.

Разом із територіальним принципом визначення кола осіб, яким належить переважне право на купівлю земельної ділянки сільськогосподарського призначення, відсутність раціонального мотиву та легітимної мети у цього права, крім всього іншого, дає підгрунтя для тверджень про дискримінацію в питаннях набуття права власності решти громадян України за ознакою місця проживання. Адже в розумінні Закону України «Про засади запобігання та протидії дискримінації в Україні» дискримінацією $є$ ситуація, за якої особа та/або група осіб за їх ознаками місця проживання зазнає обмеження у визнанні, реалізації або користуванні правами і свободами в будь-якій формі, крім випадків, коли таке обмеження має правомірну, об'єктивно обгрунтовану мету, способи досягнення якої $є$ належними та необхідними.

Порядок реалізації права переважної купівлі земельної ділянки сільськогосподарського призначення законодавством України не визначений на необхідному рівні конкретики. У прогалину правового регулювання потрапили такі елементи механізму реалізації даного переважного права як: інформування суб' єктів переважного права власником земельної ділянки про намір продати ділянку; строк очікування акцепту від суб'єктів переважного права; вибір покупця в ситуації, коли кілька суб' єктів переважного права виявили готовність купити земельну ділянку та ін.

За таких обставин необхідно з'ясувати, чи допустимо керуватись у процесі реалізації права переважної купівлі земельної ділянки сільськогосподарського призначення правовими нормами, які регулюють відносини щодо здійснення інших переважних прав на купівлю майна, а саме переважного 
права на купівлю частки у спільній власності, вдавшись до аналогії закону відповідно до ч. 1 ст. 8 ЦК України.

Для вирішення поставленого питання слід виходити зі встановлених у цьому дослідженні істотних відмінностей права переважної купівлі земельної ділянки сільськогосподарського призначення від інших переважних прав на купівлю майна, що існують в праві України. Йдеться про те, що право переважної купівлі земельної ділянки сільськогосподарського призначення не $\epsilon$ вторинним у відношенні до інших цивільних прав, а також не виконує функцій, які виконують інші переважні права на купівлю майна. Звідси робиться висновок, що для застосування норм про переважну купівлю частки у спільній власності до відносин з переважної купівлі земельної ділянки сільськогосподарського призначення в порядку аналогії закону немає підстав.

Відповідно до ч. 2 ст. 8 ЦК України у разі неможливості використати аналогію закону для регулювання цивільних відносин вони регулюються відповідно до загальних засад цивільного законодавства (аналогія права).

3 числа загальних засад цивільного законодавства, зазначених у ст. 3 ЦК України, для врегулювання відносин, пов'язаних $з$ реалізацією права переважної купівлі земельної ділянки сільськогосподарського призначення, варто спиратись на такі засади як свобода договору, добросовісність та розумність.

Зокрема, продавець ділянки сільськогосподарського призначення, щоб не допустити порушення права переважної купівлі, встановленого ч. 2 ст. 130 ЗК України, має вжити достатні заходи для повідомлення суб'єктів переважного права про свій намір відчужити ділянку. Повідомлення органів місцевого самоврядування засобами поштового зв'язку не викликає жодних складнощів. Водночас, оскільки продавець земельної ділянки сільськогосподарського призначення не має права отримати інформацію 3 реєстру територіальної громади, який ведеться для потреб реєстрації місця проживання/перебування фізичних осіб відповідно до Постанови Кабінету Міністрів України «Про затвердження Правил реєстрації місця проживання та Порядку передачі органами реєстрації інформації до Єдиного державного демографічного реєстру», то він об'єктивно не має змоги персонально проінформувати громадян України, які постійно проживають на території відповідної місцевої ради, про намір здійснити продаж земельної ділянки. Та й здійснення індивідуального повідомлення великої кількості осіб не може вважатись обов'язком продавця ділянки 3 огляду на організаційну та економічну обтяжливість таких дій, особливо якщо вони прямо не вимагаються законом. За таких умов продавцеві, який діє добросовісно і розумно, буде достатньо опублікувати оголошення про намір продажу в засобі масової інформації, який розповсюджуються у відповідній місцевості.

Визначити строк очікування акцепту від суб'єктів переважного права також можна на засадах розумності, врахувавши періодичність виходу друкованого ЗМІ, в якому публікується оголошення, масштаб відповідної місцевої ради, строк поштового обігу кореспонденції та ін. Припускається, що за звичайних умов місячний строк може вважатись достатнім.

Виходячи $з$ принципу свободи договору, елементом якого є свобода вибору контрагента, продавець вправі на власний розсуд обрати покупця земельної ділянки, якщо купити ії зголосились кілька суб'єктів переважного права.

Оскільки застосування аналогії з нормами про переважне право купівлі частки у спільній власності $\epsilon$ недопустимим, то i захист права переважної купівлі земельної ділянки сільськогосподарського призначення в разі його порушення також не може здійснюватись тим спеціальним способом, який передбачений для захисту права переважної купівлі частки у спільній власності, а саме переведення прав і обов'язків покупця на особу, чиє переважне право купівлі було порушене. Суб'єкт переважного права на купівлю земельної ділянки сільськогосподарського призначення в разі його порушення може скористатись загальними способами захисту цивільних прав, що передбачені ст. 16 ЦК України. Релевантними способами захисту можуть бути: визнання правочину недійсним; примусове виконання обов'язку в натурі та спонукання до укладення договору купівлі-продажу з суб’ єктом переважного права; відшкодування збитків та моральної шкоди.

Дослідити практику захисту переважного права на купівлю земельної ділянки сільськогосподарського призначення судами України на момент написання цієї статті не виявилось можливим, оскільки в Єдиному державному реєстрі судових рішень не було знайдено жодного судового рішення, присвяченого захисту цього права, а ч. 2 ст. 130 ЗК України згадується в окремих судових документах лише в силу явної технічної помилки замість ч. 2 ст. 120 ЗК України у справах про перехід права на земельну ділянку у разі набуття права на жилий будинок, будівлю або споруду. 
Висновки. Викладене дозволяє зробити висновки про те, що переважне право купівлі земельної ділянки сільськогосподарського призначення, передбачене ч. 2 ст. 130 ЗК України, за своєю правовою природою істотно відрізняється від інших переважних прав купівлі майна, закріплених у законодавстві України. Найпомітніші відмінності полягають в тому, що це право, по-перше, не $\epsilon$ вторинним, тобто не обумовлюється належними суб'єкту іншими цивільними правами; по-друге, надається законом суб'єктам за територіальним критерієм; по-третє, не має функціонального призначення та мети, як інші переважні права. Крім того, право переважної купівлі земельної ділянки сільськогосподарського призначення несе корупційні ризики та створює передумови для зловживання правом на шкоду вільному здійсненню права розпорядження власністю та нормальному цивільному обороту земельних ділянок, а прогалини регулювання та недосконалість формулювання норми ч. 2 ст. 130 ЗК України не забезпечують належних умов для ефективної реалізації та дієвого захисту цього права. Як наслідок, вирішення існуючих проблем у сфері правозастосування цієї норми може бути здійснене лише виходячи 3 таких приниципів цивільного права як розумність, добросовісність, свобода договору і судовий захист цивільного права та інтересу.

На основі зроблених висновків можна запропонувати лаконічний шлях вдосконалення законодавства України про купівлю-продаж земельних ділянок сільськогосподарського призначення: частину 2 ст. 130 ЗК України скасувати.

\section{Джерела та література}

1. Аномалії в цивільному праві України: навч.-практ. посібник / відп. ред. Р. А. Майданик. -Київ: Юстиніан, 2007. - 912 с.

2. Крат В. І. Переважні права: цивільно-правовий аспект: автореф. дис. ... канд. юрид. наук: 12.00.03. / В. І. Крат. - Харків, 2008. - 20 с.

3. Бондар В. В. Поняття та юридична природа переважних прав / В. В. Бондар // Університетські наукові записки. - 2011. - № 4 (40). - С. 119-125.

Носик Ю. Реализация принципов гражданского права в отношениях купли-продажи земельного участка сельскохозяйственного назначения. Статья посвящена исследованию теоретических и практических проблем, связанных с закреплением в законодательстве Украины преимущественного права на покупку земельного участка сельскохозяйственного назначения, поиску и обоснованию возможных путей их решения, исходя из основополагающих принципов гражданского права. Автор приходит к выводу, что преимущественное право покупки земельного участка сельскохозяйственного назначения, предусмотренное в ч. 2 ст. 130 Земельного кодекса Украины, по своей правовой природе существенно отличается от других преимущественных прав покупки имущества, закрепленных в законодательстве Украины, и не согласуется с концепцией, назначением и механизмом реализации таких прав. Это право не обусловлено другими гражданскими правами соответствующого субъекта; предоставляется законом субъектам по территориальному критерию; не имеет функционального назначения и цели как другие преимущественные права. Кроме того, право преимущественной покупки земельного участка сельскохозяйственного назначения несет коррупционные риски и создает предпосылки для злоупотребления правом. На основании сделанных выводов автор предлагает усовершенствовать законодательство о купле-продаже земельных участков сельскохозяйственного назначения путем отмены части 2 ст. 130 Земельного кодекса Украины. Поскольку обнаруженные в ее содержании пробелы и несовершенство формулировки не обеспечивают надлежащих условий для эффективной реализации и действенной защиты этого права. Как следствие, решения существующих проблем в сфере правоприменения этой нормы может быть осуществлено только на основании таких приниципе гражданского права, как разумность, добросовестность, свобода договора и судебная защита гражданских прав и интересов.

Ключевые слова: преимущественное право, купля-продажа, земельный участок сельскохозяйственного назначения, принципы гражданского права.

Nosik Yu. Civil Law Principles Implementation in the Relations of Purchase/Sale of Agricultural Land. The article highlights the theoretical and practical issues related to fixing the preemption right to purchase agricultural land in the legislation of Ukraine and seeks to substantiate possible ways of their solutions, based on the fundamental principles of civil law. The author concludes that the preemption right to purchase agricultural land, provided for in part 2 of articul 130 of the Land Code of Ukraine, by its legal nature differs significantly from other pre-emption rights to purchase property fixed in the 
legislation of Ukraine, since it does not cohere with the concept, purpose, and implementation mechanism of such rights. This right is not dependent on the subject's other civil rights; it is provided for by law according to territorial criteria; it has no functional prescription and purpose like other pre-emption rights. In addition, the right to pre-emptive purchase of agricultural land implies corruption risks and creates preconditions for rights abuse. Based on the conclusions, the author proposes to improve the legislation on the purchase and sale of agricultural land by repealing part 2 of articul 130 of the Land Code of Ukraine. Gaps in regulating and imperfection of the formulating of the norm of part 2 of articul 130 of the Civil Code of Ukraine do not provide appropriate conditions for the effective implementation and effective protection of this right. As a result, the solution of existing problems in the field of law enforcement of this norm can be carried out only on the basis of such principles of civil law as reasonableness, good faith, freedom of contract and judicial protection of civil law and interest.

Key words: pre-emption right, purchase-sale, agricultural land, principles of civil law.

УДК 347.124

DOI https://doi.org/10.32782/2409-4544/2020-1/11

Погребняк В.

\section{Окремі проблеми волевиявлення у ході виникнення договірних суб'сктивних цивільних прав}

Стаття присвячена дослідженню ролі волевиявлення в ході виникнення суб'єктивних цивільних прав при формуванні договірного цивільних правовідносин. Відповідна юридична схематизація розглядається, зокрема, з позицій принципу свободи волі і вільного волевиявлення, а також в контексті правозастосовчої практики вищих судових інстанцій України. Автор розглядає проблему укладення договору на підставі рішенням суду, а також аналізує сучасні тенденції практики правореалізації в частині оформлення договорів. Формується висновок про те, що механізм укладення договорів на підставі рішенням суду, який знайшов відображення на рівні положень Господарського кодексу України, може бути впроваджений і на рівні Цивільного кодексу України у зв'язку з тим, що він гармонійно вписується у систему правових засобів захисту суб'єктивних цивільних прав та може позитивно вплинути на рівень їх правового забезпечення. Укладення договору на підставі рішення суду передбачає відсутність волевиявлення одного із суб'єктів, що хоча і виглядає як відхід від загальноприйнятої концепції вільного волевиявлення як необхідної умови формування цивільного правовідношення, являє собою ефективний спосіб захисту суб' єктивних цивільних прав і законних інтересів, зокрема учасників переддоговірних відносин. 3 одного боку виникнення суб' єктивних цивільних прав вимоги і кореспондуючих їм суб'єктивних цивільних обов’язків, що входять до змісту договірних правовідносин, має відповідати потребам відповідних суб'єктів цивільного права. Однак, 3 іншого боку, слід зважати і на те, що в конкретних умовах, наприклад, за наявності попереднього договору, хоча укладення відповідного основного цивільно-правового договору може задовольняти потреби лише однієї сторони, друга сторона взяла на себе обов'язок укласти такий договір чим обмежила свою волю. Практика розгляду відповідних категорій справ господарськими судами демонструє ефективність такого правового засобу, як укладення договору за рішенням суду.

Ключові слова: виникнення прав, укладення договору, форма договору, право вимоги, рішення суду

Постановка наукової проблеми та її значення. В сучасних реаліях проблема волевиявлення у ході укладення цивільно-правових договорів, що спричиняють виникнення у їх сторін, зокрема суб' єктивних цивільних прав вимоги, проявляється переважно в двох аспектах. 3 одного боку останні тенденції практики правореалізації свідчать про існування в суспільстві запиту на спрощення форми вчинення правочинів, зокрема укладення цивільно-правових договорів. Цивільний оборот набув

(C) Погребняк В., 2020 